\title{
MATIČNE KNJIGE ŽUPE DUBRAVE 1708.-1946.: IZGUBLJENI SVJEDOCI NAŠE PROŠLOSTI
}

Marinko MARIĆ

Ivana Meštrovića 3

HR - 20000 Dubrovnik

E-pošta: marinko@maric.com.hr
UDK 272-744(497.6 Dubrave)"1708/1946"

311.43(497.6 Dubrave)"1708/1946" 314:272-744(497.6 Dubrave)"1708/1946"

Pregledni rad

Primljeno: 31. ožujka 2015.

Prihvaćeno: 24. svibnja 2015

Sažetak

Članak donosi povijesni pregled katoličke župe Dubrave u Hercegovini, od njezina osnutka 1704 . godine, te doseljavanja katolika na to područje i njihovo brojčano stanje. Dat je i povijesni pregled izdvajanja novih župa iz župe Dubrave, čime se stalno smanjivao njezin teritorijalni opseg. Glavni dio rada govori općenito o važnosti matičnih knjiga, zatim o maticama prvih župa Trebinjsko-mrkanske biskupije $s$ posebnim naglaskom na matice župe Dubrave i njihovu sudbinu. Posebice je fokus istraživanja usmjeren na sudbinu matica te župe iz 19. i 20. stoljeća koje su izgorjele 1985. i 1992. godine, čijim je uništenjem nepovratno nestala rijetko zapisana povijest velikoga dijela jugoistočne Hercegovine.

Ključne riječi: župa Dubrave, matične knjige, matični ured Crnići, povijesna demografija. 


\section{Uvod}

Predmet ovoga rada jest istraživanje sudbine nepovratno nestalih matičnih knjiga župe Dubrave iz 18., 19. i 20. stoljeća. Gubitak matičnih knjiga gotovo da znači i gubitak identiteta niza generacija s toga područja. Cilj rada jest upoznati moguće istraživače povijesne demografije i demografije uopće o sudbini nestalih crkvenih matica i preusmjeravanja na moguće druge zamjenske izvore kod rješavanja povijesno-demografskih značajki toga područja. U radu su korištene povijesno-demografske metode na temelju sačuvanih arhivskih vrela, metode intervjua, ali i ostale relevantne znanstvene metode.

\section{1. Župa Dubrave}

Župa Dubrave bila je jedna od četiri najstarije katoličke župe Trebinjsko-mrkanske biskupije. Prvotno je Trebinjsko-mrkanska biskupija imala samo dvije župe Gradac i Popovo. Župa Popovo radi lakšega upravljanja 1677. godine razdijeljena je na dvije nove, Ravno i Belenići, dok je prvot- na župa Gradac 1683. godine razdijeljena na župe Gradac i Dobrane (Dobranje). Župa Dubrave osnovana je 1704. godine od teritorija župe Dobrane koji je nakon Karlovačkoga mira 1699. godine ostao pod osmanskom vlašću. ${ }^{1}$ Obuhvaćala je široko područje od Popova na jugu do planina sjeverne Hercegovine na sjeveru. Katolički doseljenici s područja Popova i Graca područje Dubrava počeli su naseljavati početkom 17. stoljeća, čini se između 1622. i 1629. godine. Naime, biskupi Dominik Andrijašević i Benedikt Medvjedović u izvješću kongregaciji De propaganda fide ${ }^{2} 1622$. godine pišu da na tom području nema katolika. ${ }^{3}$ Međutim, sedam godina kasnije, 1629., biskup Andrijašević u izvješću Propagandi piše o tamošnjim katolicima. Javlja da u Dubravama i Podveležju ima po 60, a u Stocu i Blagaju po šest katoličkih obitelji. ${ }^{4}$ Tridesetak godina kasnije, 1664., gradački župnik Ivan Bartolučić (Bartulović) piše Trebinjsko-mrkanskom biskupu Šipionu de Martinisu u Dubrovnik da su mu "53 obitelji otišle iz župe i da se nalaze udaljene tri dana od Graca u mjestima

1 Opširnije o osnutku župe Dubrave vidi u: Milenko Krešıć, "Povijesne okolnosti osnutka i osnutak župe Dubrave u Trebinjskoj biskupiji prije 300 godina", u: Croatica christiana periodica, 57, Zagreb, 2006., str. 103-129.

2 Sveta kongregacija za širenje vjere (Sacra congregatio de propaganda fide) bila je kongregacija Svete Stolice zadužena za misijsko djelovanje i širenje katoličanstva u nekatoličkim zemljama. Od 1982. godine djeluje pod nazivom Kongregacija za evangelizaciju naroda.

3 "Ni u Ljubinju, ni u Dubravama, ni u Hrasnu nema nijednog katolika, svi su šizmatici i turci." Bazılije PandžIć, De dioecesi Tribuniensi et Mercanensi, Pontificium athenaeum Antonianum, Rim, 1959., str. 111.

4 Izvješcé biskupa Dominika Andrijaševića iz 1629. godine, u: Krunoslav Draganović, "Tobožnja 'Stjepanska biskupija - ecclesia Stephanensis' u Hercegovini", u: Croatia Sacra, 4, Zagreb, 1943., str. 55-56. S obzirom na tadašnje crkveno-političke prilike i nesporazume oko "Stjepanske biskupije" Andrijaševićeve podatke o brojčanom stanju treba uzeti s oprezom, ali u činjenicu da su katolici živjeli u tim mjestima ne bi trebalo sumnjati. 
oko Blagaja, u jednoj planini zvanoj Velež, Stolac, Nevesinje i Dubrave". Naime, za vrijeme Kandijskoga rata (1645.-1699.) katolici su iz Popova i Graca pred uskočkim upadima bježali prema unutrašnjosti. Makarski biskup Marijan Lišnjić (1664.-1686.) u izvješću iz 1672. godine piše o dijelu Makarske biskupije u Kneževini $s v$. Save gdje "preostaju samo ova sela makarske biskupije, tj. selo Tasovčići, Počitelj, Lukovac, Dubrave, Buna, Bunica, Blagaj, Stolac, Velež, Podveležje, Bijelo Polje, Jasenice, Lipete, Sajmište, poviše planine Velež do Kenčića, i u svim ovim selima, osim u Neretvi, žive rijetki katolici". ${ }^{6}$

Morejski rat (1683.-1699.) također je uzrokovao migracije katolika iz Popova i Graca prema unutrašnjosti Hercegovine. Nakon njihova masovnog doseljavanja na područje Dubrava pojavila se potreba za osnivanjem nove katoličke župe, što je učinjeno 1704. godine. Novoosnovana župa Dubrave uskoro je postala župa s najvećim brojem katolika u čitavoj Trebinjskomrkanskoj biskupiji. Prema izvješću nadbiskupa Marka Andrijaševića župa Dubrave 1733. godine, samo tridesetak godina nakon osnutka, bila je najbrojnija župa te biskupije. Imala je 1198 katolika, odnosno više od jedne trećine $(33,52 \%)$ ukupnoga broja katolika te biskupije. ${ }^{7}$ Osim što je bila najbrojnija župa, Dubrave je bila i najprostranija i najzahtjevnija župa u biskupiji. Prostirala se u krugu od 180 talijanskih milja, obuhvaćala je 34 naselja, od brda Žabe i Glumine na rubu Popova polja do Bivolja Brda i rijeke Neretve. Tu su bila sljedeća naselja: Hutovo, Previš, Glumina, Prisoje, Hrasno, Dobrane, Doljani, Sjekose, Dubravica, Čeljevo, Ljutosjer, Bjelovići, Boljuni, Kruševo, Bačnik, Njivice, Bivolje Brdo, Dubrave, Crnići, Jasoč, Trijebanj, Brštanik, Hodovo, Kremenac, Greda, Kozice, Prenj, Dabrica, Pobrđe, Čavaš, Ošanići, Košćela, Šumac i grad Stolac. ${ }^{8}$

Župa Dubrave bila je najbrojnija i kroz čitavo 18. i 19. stoljeće. Primjerice, prema popisu obitelji i njihovih članova iz 1829. godine razvidno je da je te godine obuhvaćala čak 56

5 Marko Jačov (prir.), Izvješće fra Ivana Bartolučića iz 1664. godine, u: Le missioni cattoliche nei Balcani durante la guerra di Candia (1645-1669), Vol. II., Biblioteca apostolica Vaticana, Vaticano, 1992., str. 450. Citirano prema: Milenko Krešıć, Odnosi katolika jugoistočne Hercegovine s muslimanima i pravoslavnima u vrijeme osmanske vladavine - Od osmanskoga zauzeća do Bečkoga kongresa (1482.-1815.), Filozofski fakultet Sveučilišta u Zagrebu, doktorska disertacija, Zagreb, 2008., str. 97.

6 Le missioni cattoliche nei Balcani, str. 256. Citirano prema: M. Krešıć, Odnosi katolika jugoistočne Hercegovine..., str. 96.

7 Milenko Krešić, "Katolici Trebinjsko-mrkanske biskupije prema popisu nadbiskupa Marka Andrijaševića iz 1733. godine", u: Radovi Zavoda za povijesne znanosti HAZU u Zadru, 48, Zadar, 2006., str. 439-452.

8 Selo Hrasno kao zasebno mjesto ne postoji, nego je ime za jedan predio koji čini više naselja. I Dubrave je ime za kraj u kojem se nalaze naselja: Crnići, Jasoč, Trijebanj, Brštanik, Hodovo, Kremenac, Greda, Prenj i Dabrica. Vidi: M. Krešić, "Katolici Trebinjskomrkanske biskupije prema popisu nadbiskupa Marka Andrijaševića iz 1733. godine", str. 439-452. 


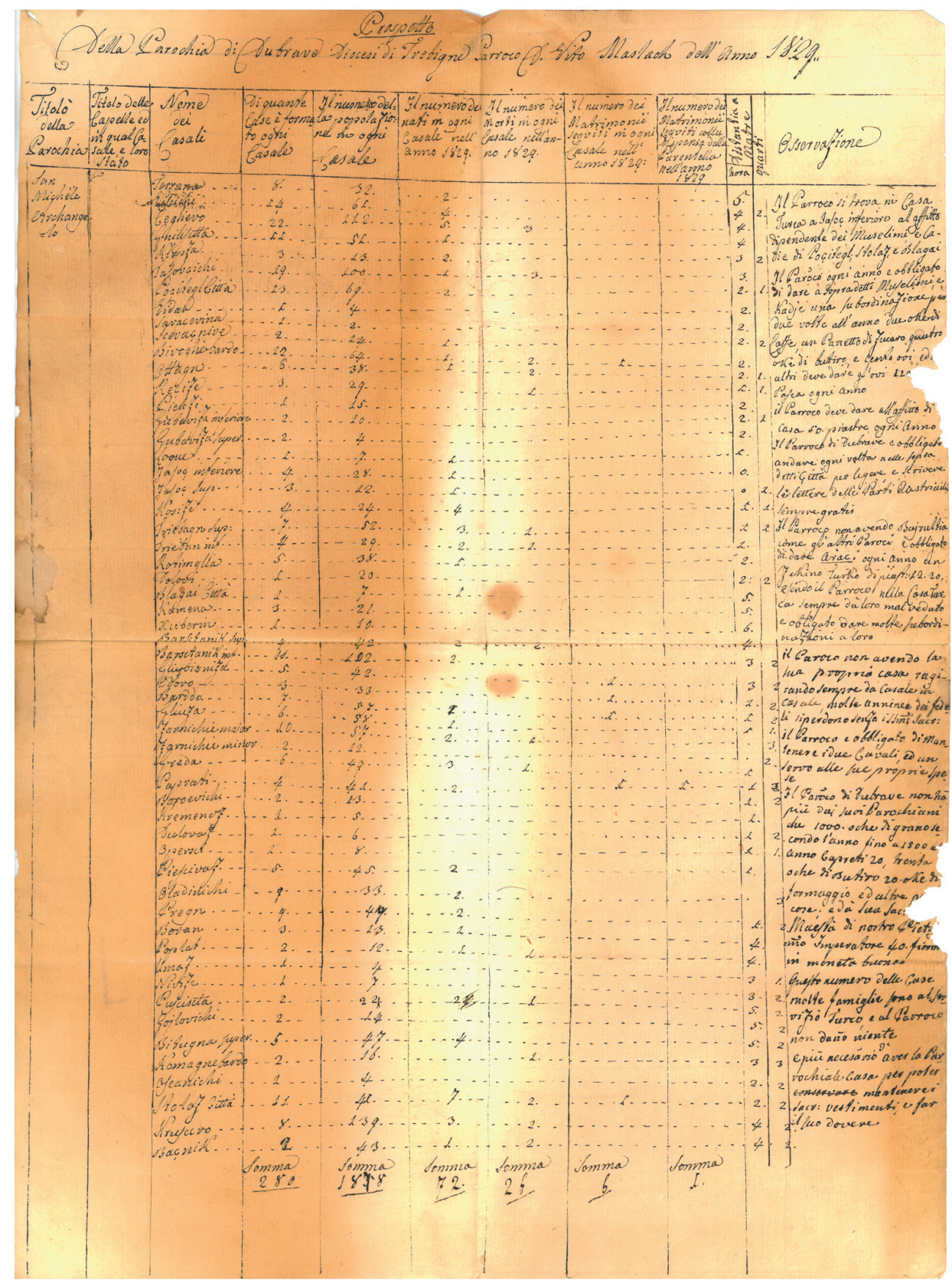

Slika 1. Popis katolika po naseljima župe Dubrave iz 1829. godine 
naselja u kojima je živjelo 280 katoličkih obitelji s 1878 članova.?

Prostrani teritorij župe Dubrave smanjivao se svakom novom crkvenom podjelom, tj. osnutkom nove župe koja je nastajala na njezinu teritoriju. Najprije je od nje 1761. godine odcijepljen prostor župe Hrasno, zatim je 1863. odcijepljen veći dio naselja buduće župe Stolac.

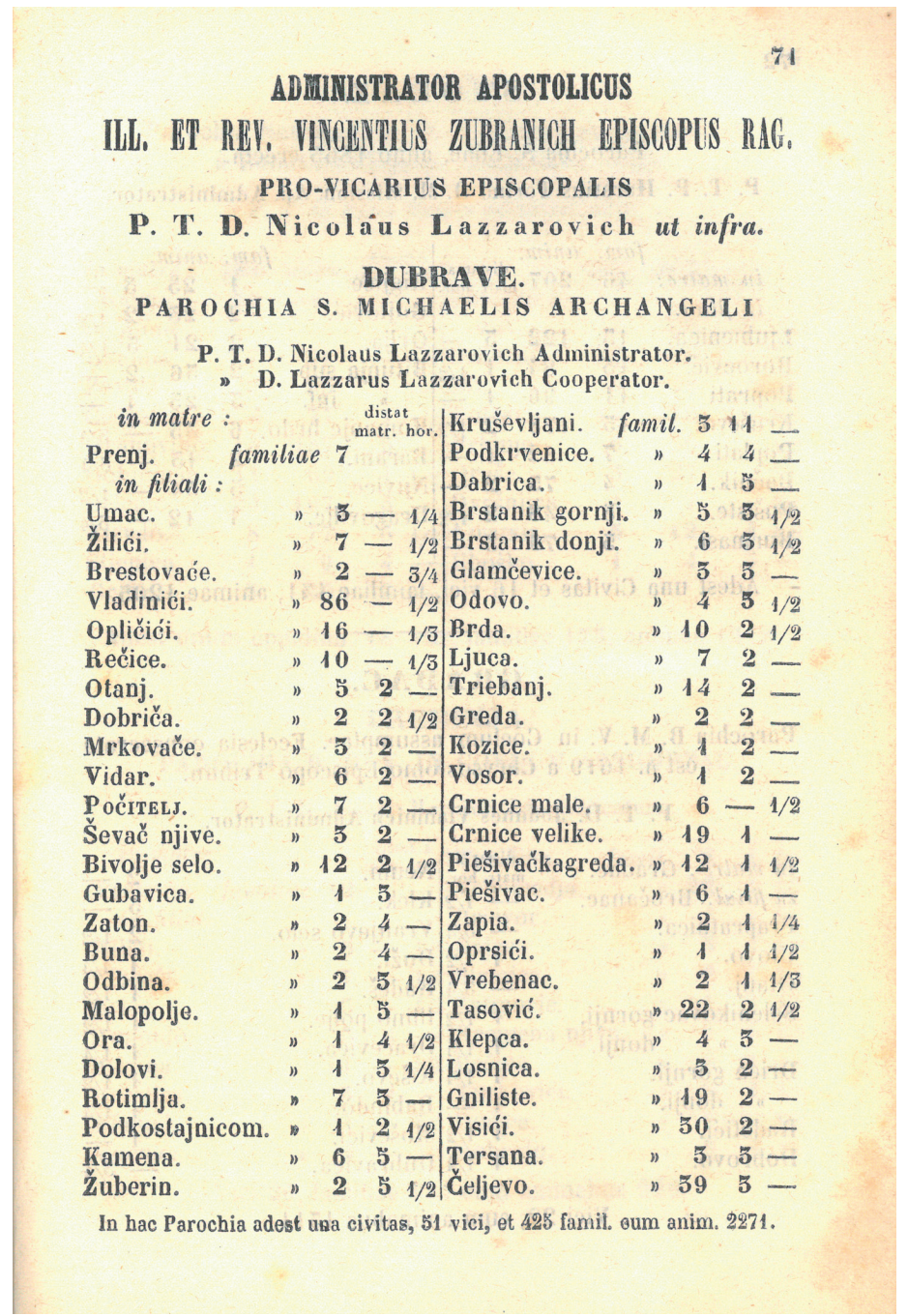

Slika 2. Popis katolika po naseljima župe Dubrave 1866. godine nakon odcjepljenja naselja župa Hrasno i Stolac ${ }^{10}$

9 Arhiv Trebinjsko-mrkanske biskupije u Dubrovniku (dalje: ATMBD), Prospetto della Parochia di Dubrave diocesi di Trebigne Parroco r. Vito Maslach dell anno 1829., kutija 1, br. 15.

10 Schematismo della Dioecesi di Ragusa per l'anno 1866. Apendice Status cleri et animarum Dioecesis Mercano - tribuniensis in Herzegovin, Dioecesi di Ragusa, Ragusa, 1866., str. 71. 
Godine 1874. odcijepljeno je područje novoosnovane župe Gabela (Dračevo, Čeljevo, Doljani, Klepci), ${ }^{11}$ 1891. područje župe Blagaj, 1899. područje župe Nevesinje, 1917. područje župe Rotimlja, 1969. područje župe Domanovići i napokon 1977. područje župe Aladinići. ${ }^{12}$ Krajem 19. stoljeća župi Dubrave promijenjen je naziv pa od tada nosi ime sjedišta župe - Župa Prenj.

\subsection{Matične knjige župe Dubrave}

Matične su knjige prvorazredna i najvjerodostojnija povijesna vrela za mikroistraživanje stanovništva određenoga područja. One su službeni dokumenti u kojima su zabilježeni rođenje/krštenje, vjenčanje ili smrt neke osobe i fiksirani trenutci na temelju kojih se može rekonstruirati demografska i opća povijest određene mikroregije. ${ }^{13}$ Kvalitetnom analizom i usporedbom $s$ ostalim vrelima, iz njih se, osim demografskih, daju iščitati i socijalne prilike. Naime, one su svjedoci povijesti nedaća, u njima su zapisane smrti od gladi, suša, poplava, epidemija, ratova, neimaštine i sl. One su neprijeporno najvažnija vrela koja dolaze iz davnoga i "izgubljenoga svijeta" u kojima se zrcale životi naših predaka. "Matične su knjige najdramatičnija paradigma kršćanske Europe od srednjovjekovlja do danas, fascinantna dokumentacija o čovjeku razapetom između rođenja i smrti u uvijek iznova ponavljanim ciklusima života novih i novih naraštaja..." ${ }^{14}$

Prva je službena odredba o matičnim knjigama, koja je provedena u praksi, bila ona nantskoga biskupa Henrija Le Barbua iz 1406. godine. ${ }^{15}$ Tom je odredbom biskup naredio župnicima u svojoj biskupiji da vode evidencije o krštenicima, njihovim roditeljima i kumovima. Prekretnicu u vođenju crkvenih matica predstavlja odluka čuvara državnoga pečata u Engleskoj, Thomasa Cromwella, izdana 5. rujna 1538., kojom on, u ime vrhovnoga poglavara Anglikanske crkve, kralja Henrika VIII., naređuje župnicima da vode knjige krštenih, vjenčanih i umrlih. ${ }^{16}$ Tom su se odlukom prvi

11 Radilo se o području s lijeve strane Neretve, jer je na desnoj već postojala župa s istim imenom - Župa Gabela, koja je pripadala Hercegovačkom apostolskom vikarijatu.

12 Ivica Puljić, "Nastanak novih župa na povijesnom području povijesne župe Dubrave", u: Milenko Krešić (prir.), 300 godina župe Dubrave, Župe: Aladinići - Celjevo - Domanovići - Dračevo - Hrasno - Prenj - Rotimlja - Stolac; Općine: Čapljina - Neum Stolac - Ravno; Matica hrvatska: Čapljina - Neum - Stolac - Aladinići (Stolac), 2006., str. 109-133.

13 Dražen Vlahov - Jakov Jelinčić - Danijela Doblanović, "Uvod", u: Vjesnik istarskog arhiva, 11-13, Pazin, 2004.-2006., str. 11.

14 Miroslav Bertoša, "Matične knjige - arhivsko vrelo o demografskim previranjima predindustrijske Europe", u: Vjesnik Državnog arhiva u Rijeci, 41-42, Rijeka, 2000., str. 350.

15 Ivo Ficović, "Zbirka matičnih knjiga Historijskog arhiva u Dubrovniku", u: Arhivski vjesnik, 25, Zagreb, 1982., str. 11.

16 Knjige su župnici morali čuvati u osiguranoj škrinji i u nazočnosti dvojice crkvenih starješina svake nedjelje unositi podatke za protekli tjedan. Za nepoštivanje te odredbe bile su predviđene i novčane kazne. Vidi: I. Ficović, "Zbirka matičnih knjiga Historijskog arhiva u Dubrovniku", str. 12. 
put uvele univerzalne odredbe o vođenju matičnih knjiga koje su vrijedile za neku crkvenu zajednicu.

Jačanje protestantizma i pokušaj vraćanja odijeljenih kršćana u krilo Katoličke crkve bili su među glavnim razlozima sazivanja Tridentskoga koncila 1545 . godine. ${ }^{17} \mathrm{Na} 24$. sjednici Koncila, 11. studenoga 1563., donesena je odredba o vođenju matica krštenih i vjenčanih. ${ }^{18}$ Rimski je obrednik (Rituale Romanum Apostolicae Sedis) 1614. godine dopunio tu odredbu s obvezom vođenja matica krizmanih, umrlih i Stanja duša. ${ }^{19}$

Najstarijom crkvenom maticom smatra se matica krštenih iz 1451. godine koja je sačuvana u župi Ille-et-Villaine u Bretagni, u Francuskoj. U Hrvatskoj je najstarija sačuvana matica krštenih iz 1483. godine, sačuvana u Umagu. ${ }^{20}$ Najstarija sačuvana matica u Bosni i Hercegovini jest matica krštenih župe Kraljeva Sutjeska iz 1641. godine. ${ }^{21}$

Zbog raznoraznih okolnosti trebalo je proći više od stotinu godina od Tridentskoga koncila kako bi se obveza vođenja matica počela primjenjivati u župama Trebinjsko-mrkanske biskupije. ${ }^{22}$ Najstarija sačuvana matica te biskupije, a i čitave Hercegovine, jest matica krštenih župe Rupni Do. Njezin je prvi upis iz 20. listopada

17 Tridentski je koncil bio devetnaesti ekumenski koncil koji se, s prekidima, održavao od 1545. do 1563. godine. Sazvao ga je papa Pavao III. radi obnove Crkve, pokušaja pomirenja s protestantima i zauzimanja stava prema reformaciji.

18 Osim spomenutih, kao razlog za uvođenje matica bila je i potreba da se stane u kraj nevaljanim i skandaloznim ženidbama između krvnih srodnika, otmicama djevojka i sl. Problem nevaljanih vjenčanja u znatnoj se mjeri nastavio i nakon Koncila. Primjerice, u Ravnom i Orahovu Dolu u Popovu umaknuća djevojaka toliko su bila raširena da je taj problem "bio iznesen i pred sv. Oca i pred sv. Oficij koji su trebinjsko-mrkanskom biskupu poslali rješenje da krivce za to protjera i izopći iz Crkve". Vidi: KRunoslav Draganović, "Tobožnja 'Stjepanska biskupija - ecclesia Stephanensis' u Hercegovini", u: Croatia Sacra, 4, Zagreb, 1934., str. 35.

19 Rimski je obrednik propisivao vođenje crkvenih obreda i vođenje matičnih knjiga. Bio je obvezujući za čitavu Zapadnu crkvu i gotovo se nije mijenjao do Drugoga vatikanskog koncila (1962.-1965.). Izdao ga je 1614. godine papa Pavao V. Prvi cjelovit prijevod Rimskoga obrednika na narodni jezik bio je hrvatski prijevod isusovca Bartola Kašića iz 1636. godine. Opširnije vidi u: Slaven Bertoša, Život i smrt u Puli: Starosjedioci i doseljenici od XVII. do XIX. stoljeća, Skupština Udruga Matice hrvatske Istarske županije, Pazin, 2002., str. 27.

20 Vladimir Stipetić - Nenad Vekarić, Povijesna demografija Hrvatske, Zavod za povijesne znanosti HAZU u Dubrovniku, Zagreb - Dubrovnik, 2004., str. 28.

21 Mirко BoвAš, "Upotreba slovnog znaka (đerva) u praksi pisara matice krštenih iz Kraljeve Sutjeske od godine 1641.-1727.", u: Marko Karamatić (prir.), Zbornik radova o fra Andelu Zvizdoviću, Franjevačka teologija Sarajevo - Franjevački samostan Fojnica, Sarajevo - Fojnica, 2000., str. 459-475.

22 Biskup Primi 1675. godine piše kako u "tim mjestima, koja su pod turskom vlašću, Tridentski sabor nije primljen, ipak prethodni biskup, kao i sadašnji, prema mogućnostima mjesta održava ga, kako u ženidbi tako i u drugim stvarima". Vidi: "Izvješće biskupa Antuna Primija iz 1675. godine", u: Marko JaČov (ur.), Le missioni cattoliche nei Balcani tra le due grandi guerre: Candia (1645-1669) Vienna e Morea (1683-1699), sv. 3, Biblioteca apostolica Vaticana, Vaticano, 1998., str. 349-361; ANDRIJA Nikić, "Jugoistočna Hercegovina prije 300 godina (1675.-1975.)", u: Kršni zavičaj, 7, Humac, 1974., str. 12. 
1708. ${ }^{23}$ Župa Gradac također ima sačuvane svoje najstarije matice. Prvi je upis iz 20. veljače 1709., tri mjeseca nakon onoga u Rupnom Dolu. ${ }^{24}$ Župa je Ravno također imala matice od 1708. godine, a nastradale su početkom 19. stoljeća. $^{25}$

Vjerojatno su postojale još starije matice, jer trebinjsko-mrkanski biskup Antun Primi u izvješću Propagandi 1675. godine piše kako je "...prisilio župnike da vode matice krštenih, a to se, ne samo u ovoj biskupiji nego u svim krajevima Turske, nije nikada običavalo". ${ }^{26}$ Postoji nekoliko argumenata koji ukazuju da su matice iz toga vremena trebale postojati. Naime, od šezdesetih godina 17. stoljeća na službi u Trebinjsko-mrkanskoj biskupiji bili su bosanski franjevci (u župi Gradac fra Petar iz Mekanice, a u župi Popovo fra Stjepan iz Sutjeske i kasnije fra Ivan Bartolučić - Bartulović), koji su u Bosni već tridesetak godina vodili matice (od 1641. godine). Nadalje, Ilija Bošković, prvi ravanjski župnik, župu je preuzeo 1677. godine, odmah nakon povratka sa studija iz Ferma, pa je morao biti upoznat $s$ odredbama Tridentskoga koncila o obveznom vođenju mati- ca. Napokon, za vjerovati je da su se župnici morali pridržavati biskupove naredbe o obveznom vođenju matica. No, o eventualnim maticama do 1708. godine nema traga. Sljedeći je trebinjsko-mrkanski biskup, Antun Righi, 1708. godine ponovio obvezu vođenja matica i propisao formu iz Rimskoga obrednika u kojoj ih treba voditi. Njegova je naredba izvršena jer je te, ili sljedeće, godine započeto vođenje matica u tri župe biskupije, Ravnom, Gracu i Rupnom Dolu, dok za četvrtu, župu Dubrave, to nije poznato.

Nisu sačuvane starije matične knjige župe Dubrave. Sačuvane su tek od 1946. godine te prijepisi od 1917., koji se čuvaju u arhivu Biskupije u Mostaru. Zasigurno je i župa Dubrave, kao i preostale tri tadašnje župe Trebinjsko-mrkanske biskupije, Ravno, Gradac i Rupni Do, imala matice od 1708. godine. O njihovu postojanju nisu ostali pisani tragovi, ali vjerojatno su uništene u požaru župnoga ureda i župne kuće u Prenju 1832. godine. Naime, provikar Dominik Sokolović u pismu Kongregaciji od 27. srpnja 1832. traži pomoć za župnike Trebinjsko-mrkanske biskupije, na-

23 Vjerojatno su matice u Rim odnijeli talijanski misionari koji su bili na službi u jugoistočnoj Hercegovini sredinom 19. stoljeća. Osamdesetih godina prošloga stoljeća Andrija Nikić matice je pronašao u Arhivu Propagande u Rimu.

24 Novija paginacija ukazuje da nedostaje prvi list, tako da se taj prvi upis nalazi na 3. paginiranoj stranici.

25 U Državnom arhivu u Dubrovniku pronađen je prijepis krštenja iz 1786. godine gdje je tadašnji župnik, Feliks iz Dubrovnika, prepisao upis krštenja Ivana Boškovića iz 1740. godine. Župnik navodi da se original upisa nalazi u matici krštenih župe Ravno iz 1708. godine na stranici 61. Državni arhiv u Dubrovniku (dalje: DAD), Fedi ed attestati, sv. 5, nenumerirani dokument između f. 24 i 25. Opširnije vidi u: Marinko Marić, Stanovništvo Popova u Hercegovini: Ravno, Zavod za povijesne znanosti HAZU u Dubrovniku, Dubrovnik, 2015., str. 21.

26 Le missioni cattoliche nei Balcani, str. 349-361; A. Nikić, "Jugoistočna Hercegovina prije 300 godina (1675.-1975.)", str. 19. 
vodeći kao najpotrebitijega župnika u Dubravama "...kojemu je spaljena kuća usred nemira pokrenutih protiv otomanske vlade. U požaru je izgubio dio svetih stvari, a izgorjele su i župne knjige". ${ }^{27}$ To je jedino dosad poznato arhivsko vrelo koje spominje najstarije matice župe Dubrave. Čini se da je vatra bila pogubna i za matice koje su vođene nakon 1832. godine. Naime, vatra je kroz prošlost bila veliki neprijatelj i uništavajući čimbenik materijalne i kulturne baštine, pa tako i crkvenih matica. Odnijela je i one najstarije iz župe Hrasno, od 1761. do 1822. godine. Prisebnošću don Joze Zovke spašene su one najstarije iz župe Ravno, ali su izgorjele novije matice iz 20. stoljeća i dvije knjige Stanje duša, iz 1882. koju je sastavio don Vide Putica i iz 1925. godine koju je sastavio don Marko Zovko. ${ }^{28}$

Daljnju sudbinu matica župe Dubrave, koje su vođene od 1832. do 1945. godine odredio je Drugi svjetski rat i nova vlast. Naime, po završetku Drugoga svjetskog rata komunističke su vlasti došle na vlast i na svim područjima počele provoditi smjernice ateističke ideologije. Pogotovo su represiju provodili prema Katoličkoj crkvi, koju su optuživali za suradnju $s$ ustaškom vlašću. Osim uhićenja i ubijanja biskupa i svećenika, onemogućavanja i zabrane vjeronauka u državnim školama, zabrane vjerskoga tiska, represija se provodila i kroz oduzimanje crkvene imovine, između ostaloga i crkvenih matica. Naime, 1. travnja 1946. donesen je Zakon o matičnim knjigama. ${ }^{29}$ Tim su zakonom uvedene građanske ili civilne matične knjige, a njihovo vođenje povjereno je matičarima u mjesnim odborima. Župni uredi su im morali predati crkvene matice koje su se dotad kod njih čuvale. S 9. svibnjem 1946. morale su biti zaključene sve župne matice koje su se otad morale koristiti kao zajedničke matice za Crkvu i državu. Zupnicima je bilo zabranjeno svako daljnje upisivanje u zaključene župne matice, pa makar u matici bila popunjena samo jedna stranica. Pojedini župnici, koji su u dobroj vjeri naknadno unijeli poneki upis, kažnjeni su visokim globama. ${ }^{30}$

27 Provikarski arhiv u Stocu (dalje: PVAS), Dopis provikara Dominika Sokolovića kongregaciji De propaganda fide od 27. srpnja 1832. Korespondencija 1832., f. 16-17.

28 "Žao mi je da tom zgodom ne odnesoh i Stanje duša, kojega je pok. Don Vide temeljito i točno sastavio tamo oko 1882 . Bijaše velika knjižurina pa mi se nije dalo nositi je. I Don Marko Zovko bio je sastavio novi tamo oko 1925, vrlo točan. I on je izgorio s istog razloga." Tako je Jozo Zovko, župnik župe Ravno (1932.-1942.) opisao spašavanje crkvenih matica iz župne kuće u Ravnom koju su "partizani spalili u noći 22/23. rujna 1943. godine." Vidi: Jozo Zovko, "Ubikacija crkve sv. Petra Apostola u Zavali, Popovo Polje, Hercegovina", u: Ravno, Popovo - četiri slike iz povijesti kraja, "Ljetopis Popova" Ravno - Općinsko vijeće Ravno - "Moderna vremena" Zagreb, Ravno - Zagreb, 1997., str. 87; Stjepan Batinović, "Iz pisama", u: Vjesnik župe Hrasno, 7, Hrasno, 1968., str. 35.

29 Službeni list FNRJ, br. 29, od 9. travnja 1946., Beograd, 1946., str. 19-20.

30 Takav je slučaj bio u Čapljini, gdje je župnik kažnjen s 3000 dinara globe. Naime, župniku je, preko državnoga matičara, iz sreza tek u kolovozu 1946. javljeno da ne smije više ništa naknadno unositi u matice i župnik je odmah poslušao i strogo se te naredbe držao, što je i na sudu konstatirao, ali ga je ipak sud osudio na globu jer je u međuvremenu od 9. svibnja pa do kolovoza, kada mu je državni matičar uručio nalog, unio nekoliko upisa. Opširnije vidi u: Miroslav Akmadža, "Položaj Katoličke crkve u Hercegovini u 
U Službenom listu FNRJ od 12. siječnja 1949. objavljen je Zakon o izmjenama i dopunama Zakona o državnim matičnim knjigama. Između ostaloga taj je Zakon donio sljedeću odredbu: "Tko izvrši krštenje ili odgovarajući obred prije nego što je podnesena prijava rođenog imena za upis u matičnu knjigu, kaznit će se novčano do 2000 dinara ili popravnim radom do dva mjeseca. Istom kaznom kaznit će se i tko izvrši pogreb ili obred pogreba prije prijave smrti matičaru odnosno bez dozvole nadležnoga narodnog odbora. Prema osobi, koja u iznimnim i hitnim slučajevima izvrši krštenje ili odgovarajući obred, odnosno pogreb ili obred pogreba prije nego što je izvršena prijava matičaru ili bez odobrenja nadležnog narodnog odbora, neće se primjenjivati kazne određene u prethodnim stavkama ako navedene slučajeve prijavi matičaru u roku od četrdeset osam sati od izvršenja krštenja, pogreba odnosno obreda." Također se određuje da "vjerski predstavnik koji izvrši nove ili naknadne upise u matične knjige iz čl. 48. ovog
Zakona koje su zaključene, kaznit će se novčano do 10,000 dinara ili popravnim radom do tri mjeseca. Osim kazne iz prethodne stavke matične knjige mogu se oduzeti od vjerskog predstavnika i predati na čuvanje nadležnom matičaru". ${ }^{31}$

Taj zakon nije zaobišao ni matične knjige župe Dubrave. Oduzete su iz župnoga ureda u Prenju i prenesene u matični ured Crnići. Iako su pojedinci kasnije imali pristup i uvid u oduzete crkvene matice i iz njih prepisivali određene podatke, čini se, nije bilo svijesti ni savjesti, a možda ni mogućnosti, fotokopirati ih ili na neki drugi način umnožiti i na taj način sačuvati ih od propasti koja ih je kasnije zadesila. ${ }^{32}$ Njihova je sudbina zapečaćena 1985. godine kada je izgorio matični ured Crnići i sve knjige koje su se u njemu nalazile. Naime, matični se ured nalazio u zajedničkoj zgradi (bivšoj kasarni) u sklopu mjesne zajednice Crnići. Tadašnji "sekretar" mjesne zajednice ( $\mathrm{R}$. T.) napravio je određene financijske malverzacije s novcem koji je priku-

prvim godinama komunističke vladavine", u: Ivica Lučić (ur.), Hum i Hercegovina kroz povijest, II., Zbornik radova s Međunarodnoga znanstvenog skupa u Mostaru, Hrvatski institut za povijest, Zagreb, 2011., str. 499.

31 Službeni list FNRJ, br. 4 od 12. siječnja 1949., Beograd, 1949., str. 38-39. Opširnije vidi u: Miroslav Akmadža, "Oduzimanje crkvenih matičnih knjiga u Hrvatskoj u vrijeme komunizma", u: Croatica christiana periodica, 61, Zagreb, 2008., str. 108.

32 Tragajući godinama za ostatcima izgorjelih matičnih knjiga, autor ovoga članka obišao je sve relevantne institucije (Općina Stolac, Matični ured Stolac, MUP Stolac, Sud u Stocu i Čapljini) pokušavajući ući u trag tim ostatcima. Obavljen je velik broj razgovora s izravnim i neizravnim sudionicima i poznavateljima navedenoga događaja: Boškom Boškovićem, tadašnjim policijskim istražiteljem koji je vodio istragu o slučaju, Nikolom Ragužem, djelatnikom tadašnjega SUP-a, Perom Sutalom, djelatnikom tadašnje Skupštine općine Stolac, Vinkom Matićem, tadašnjim i Martinom Stankovićem, prijašnjim matičarom Matičnoga ureda Crnići, Karmelom Marić, voditeljicom Matičnoga ureda Stolac, Markom Ragužem, bivšim predsjednikom Općinskoga suda u Stocu, te Nikolom Mandićem i Ratkom Perićem koji su imali uvid u matice prije njihova uništenja. Svima njima zahvaljujem na susretljivosti i pomoći u traženju te utvrđivanju točnih činjenica o tim maticama. 
pljan za humanitarnu nakanu i, htijući prikriti svoje nedjelo, zapalio je dokumentaciju koja se odnosila na taj novac. ${ }^{33}$ Međutim, vatra se iz ureda mjesne zajednice proširila i na matični ured u kojem su se nalazile sve matice, crkvene i civilne, i uništila ih. Kako tom prilikom nisu u potpunosti izgorjele, većinom su bile nagorjele, njihovi su ostatci pohranjeni u prostorije Općine Stolac. ${ }^{34}$ No, čini se da im je vatra bila neizbježna sudbina. Tijekom ratnih događanja u Stocu, 1992. godine, prostorija u kojoj su, uz ostale porezne knjige, bili pohranjeni i njihovi ostatci izgorjela je do temelja. Tako su nestali i posljednji ostatci s mukom, i uz voštanicu, pisane prošlosti katoličkoga stanovništva područja Dubrava, Stoca i okolnih mjesta koja su pripadala nekadašnjoj drevnoj župi Dubrave.

\section{Zaključak}

O maticama župe Dubrave znalo se veoma malo pa se ovim radom pokušalo osvijetliti njihovu prošlost i točno utvrditi njihova sudbina. Bilo je poznato da su izgorjele u požaru matičnoga ureda 1985. godine. Međutim, nije bilo poznato od koje su točno godine vođene, jesu li bile matice krštenih, vjenčanih ili umrlih? $\mathrm{Na}$ temelju arhivskih vrela i dugogodišnjega traganja za ostatcima izgorjelih i nagorjelih matičnih knjiga napravljena je rekonstrukcija i utvrđena njihova sudbina. Premda se na temelju dostupnih vrela ne može sa sigurnošću utvrditi od kada je župa Dubrave imala matične knjige, ipak određeni pokazatelji upućuju da je i ona, poput preostale tri župe Trebinjsko-mrkanske biskupije, imala matice od 1708. godine. Arhivska vrela svjedoče o uništenju tih matica u požaru 1832. godine. Matice vođene nakon te pa do 1946. godine također su nastradale u namjerno izazvanom požaru matičnoga ureda u Crnićima 1985. godine. Na temelju svjedočanstava izravnih svjedoka toga događaja i policijsko-sudskih istražitelja sa sigurnošću se može zaključiti kako te matice nisu u potpunosti izgorjele. Njihovi su ostatci tada bili pohranjeni u zgradu Skupštine općine Stolac, ali je i njih dokrajčio ratni oganj 1992. godine. 
Registers of the parish of Dubrava from 1708-1946: the lost witnesses of our past

\section{Summary}

The article presents the results of research based on the analysis of archive sources about the church parish registers of Dubrava in Herzegovina, from its foundation in 1704 until the destruction of the registers in 1985. The author describes the importance of registers as the most relevant sources for historical, demographic and genealogical research, their history, origin and development. The paper delivers details on the oldest preserved registers in the world, then in Croatia, Bosnia and Herzegovina and in the area of Trebinje-Mrkan, including the area of the parish of Dubrava. A brief history of the parish, its territorial scope and the church divisions, i.e. the establishment of new parishes that split from the Dubrava parish are also described. The main part comprises the historical facts of the parish registers of Dubrava. According to sources, their destiny had been traced before 1832, when they were destroyed in fire. However, what was unknown refers to the records kept after this year, when the Communist authorities confiscated the registers from the parish office in Prenj and deposited them in the Registry office of Crnici. There they suffered the same fate as the older registers, they were mostly destroyed by arson in 1985. Having followed the traces of the register remains which were not completely burnt but were, more or less, charred, the author conducted interviews with the then registrar, police investigators and other eye witnesses of the event and on the basis of their testimony tried to track the rest of the registers.

Keywords: the parish of Dubrave, register books, registry office of Crnici, historical demography. 